\title{
NOTE
}

\section{Perforation disease affecting UIva sp. cultured in Israel on the Red Sea}

\author{
Angelo Colorni \\ Israel Oceanographic and Limnological Research Institute, National Center for Mariculture, PO Box 1212, Eilat 88112 , Israel
}

\begin{abstract}
A disease affecting a local Ulva sp. in culture at Eilat (Israel, Red Sea) is reported. 'Green spots' dotted the algal thallus and gradually enlarged into perforations. A variety of fouling microorganisms settled in these lesions, while the protoplasm of surrounding cells assumed a crescent shape. Two microscopic algae grew on the diseased thalli. One of them, with a filamentous morphology, branched out from the edges of the perforations and was presumed to be an allomorphic form of the same Ulva sp., developing from the typical foliar thallus in response to unfavourable environmental conditions and bacterial proliferation. Diseased thalli did not decay but their growth was stunted. Involvement of epibiontic microorganisms in the disease outbreak was ruled out. The onset of the lesions was probably triggered by traumatic events to which the alga was subjected in the culture conditions.
\end{abstract}

A local variety of sea lettuce Ulva $\mathrm{sp}$. is cultivated at the National Center for Mariculture of the Israel Oceanographic and Limnological Research Institute (IOLR) in Eilat, on the Red Sea. Utilization of macroalgal beds for removal of excess nutrients from the waste water outflow of the aquaculture facilities has been envisioned in the past (Gordin et al. 1981), and the potential of Ulva sp. for trapping nitrogenous and phosphorous products is presently under investigation.

Culture conditions. Ten $600 \mathrm{l}$ tanks with continuous aeration and flow-through seawater were used. The effects of water-retention-time, aeration, stocking density and nutrient addition on the algal nutrient absorption and growth rate were under study (Cohen \& Neori, IOLR, Eilat, unpubl.). Salinity ranged between 40 and $41 \%$, which is normal for the northern Gulf of Eilat. Temperature fluctuations were 15 to $22^{\circ} \mathrm{C}$ in winter and 23 to $27^{\circ} \mathrm{C}$ in summer. As a part of the experimental procedure, the tanks were emptied once a week and the thalli drained of excess water, weighed and sampled.

Pathology. A disease affecting the experimental cultures of Ulva sp. was first observed in March 1988. The disease started as small 'green spots' dotting the thallus (Fig. 1), consisting of atrophied, densely packed cells which gradually lost their protoplasm. The lesions subsequently enlarged and developed into perforations (Fig. 2). A variety of fouling microorganisms (the ciliate protozoan Zoothamnium sp., Leucothrix-like filamentous bacteria, diatoms, etc.) settled in these lesions (Fig. 3). Often, a microscopic filamentous alga seemingly growing between cell layers was observed extending hyphae-like uniseriate branches from the perforation edges (Fig. 4). Presence of chlorophyll, and thus the algal nature of these branches, was confirmed by epifluorescence microscopy. The protoplasm of cells surrounding perforations assumed a crescent shape (Fig. 5). Another microscopic alga grew on the thallus of these diseased Ulva, but did not perforate it (Fig. 6). All 10 Ulva tanks were affected, although to different degrees, with thalli presenting up to 15 or 20 green spots' or pinhead-size perforations per $\mathrm{cm}^{2}$. Diseased thalli did not decay, but their growth was stunted. Although epibiontic filamentous bacteria, nematodes and copepods were also observed associated with unaffected Ulva growing in other parts of the IOLR system, the possibility that they initiated the disease was considered, and their role in the pathogenic process tested. Healthy Ulva thalli were challenged with diseased ones by holding 3 fragments of each, of about $100 \mathrm{~cm}^{2}$, in a Parafilm-sealed $1 \mathrm{l}$ beaker at room temperature for up to 8 wk. However, no 'contagion' occurred. Furthermore, no remission was observed during this period in the diseased fragments and the damage in this small self-contained system appeared to be irreversible, despite the static conditions in which the thalli were kept.

Discussion. Similar conditions have been reported previously in nori Porphyra sp. in Japan as 'green spot disease' (Saito et al. 1972) and 'perforation disease' (Suto \& Umebayashi 1954, Nozawa \& Nozawa 1957. Suto et al. 1972). In these cases, loss of cell protoplasm 

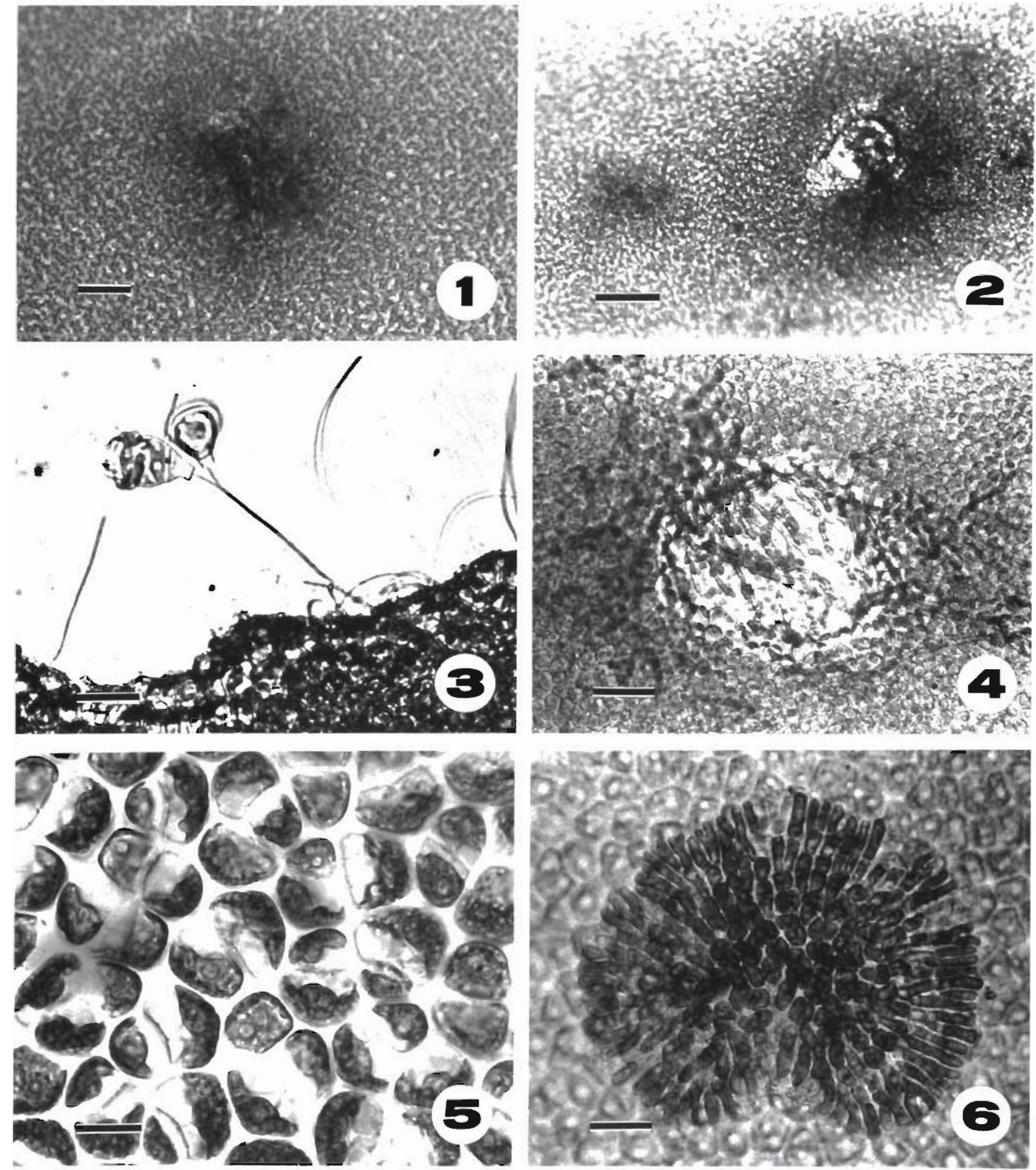

Figs. 1 to 6 . Ulva sp. Fig. 1. Typical 'green spot' in its initial stage; bar $=100 \mu \mathrm{m}$. Fig. 2. Developing perforation; bar $=200 \mu$ m. Fig. 3. Fouling microorganisms on the edge of the perforation; bai $=35 \mu \mathrm{m}$. Fig. 4. Filamentous alga, presumably an allomorphic form of the same Ulva sp., spreading out of the edges of a. perforation; bar $=65 \mu \mathrm{m}$. Fig. 5 . Crescent shape of protoplasm in the cells surrounding a perforation; $\mathrm{ba}=15 \mu \mathrm{m}$. Fig. 6. Microscopic epibiontic alga growing on diseased thallus; bar $=25 \mu \mathrm{m}$ 
was suspected of being triggered by traumatic damage. More recently, Tsukidate (1983) speculated that under adverse environmental conditions Porphyra exudes certain amino acids which stimulate growth of opportunistic phycopathogenic bacteria, leading to cell necrosis. Among Ulva species, bacteria and unfavourable physical conditions prevailing in the habitat can also stimulate polymorphism. By exposing Ulva lactuca to high concentrations of the marine bacteria associated with the alga, Provasoli \& Pintner (1980) were able to induce the formation of a filamentous vegetative thallus similar to that growing from the perforation edges of our Ulva sp. This suggests that the typical expanded foliar thallus and the filamentous alga in the perforations are actually allomorphic forms of the same Ulva sp., with the latter developing in response to unfavorable environmental conditions and intensive bacterial proliferation in the lesions. This versatile nature of the alga and the ability of some species to govern their own morphology (Provasoli \& Pintner 1980) makes the assignment of taxonomic position problematic. In the course of extensive work on dietary preferences of 3 herbivorous siganid fish in the Gulf of Eilat, Lundberg \& Lipkin (1979) examined samples of Ulva, but were similarly unable to identify them. Since appearance of the condition tended to decrease in intensity when water agitation was reduced, and transmission of the disease to healthy thalli could not be obtained experimentally by contact, it was considered that excessive turbulence in the Ulva tanks and the unavoidable handling during harvest were the probable cause of the onset of the observed lesions.

Responsible Subject Editor: Professor S. Bonotto, Mol, Belgium
Acknowledgements. Thanks are due to Dr A. Neori and Ms I. Cohen (IOLR) for bringing the disease to my attention. I am indebted to Prof. P. Ghittino (Istituto Zooprofilattico Sperimentale del Piemonte, Liguria e Valle d'Aosta, Torino, Italy) for having provided me with bibliographic references and invaluable footnotes, and to Prof. T Sano (Department of Aquatic Biosciences, Tokyo University of Fisheries, Japan) for translations from the Japanese.

\section{LITERATURE CITED}

Gordin, H., Motzkin, F., Hughes-Games, W. L., Porter, C. (1981). Seawater mariculture pond - an integrated system. In: Rosenthal, H., Oren, O. H. (eds.) Europ. Maric. Soc., Special Publ. \#6. Prinses Elisabethlaan, Bredene, Belgium, p. 1-13

Lundberg, B., Lopkin, Y. (1979). Natural food of the herbivorous rabbitfish (Siganus spp.) in northern Red Sea. Botanica mar. 12: 173-181

Nozawa, K., Nozawa, Y, (1957). Studies on the protoplasm of sea algae - II. On the 'perforation disease' of Porphyra (asakusa-nori). Bull. Jap. Soc. scient. Fish. 22 (11): 694-700 (Japanese)

Provasoli, L., Pintner, I. J. (1980). Bacteria induced polymorphism in an axenic laboratory strain of Ulva lactuca (Chlorophyceae). J. Phycol. 16: 196-201

Saito, Y., Matsusato, T., Yoshikawa, K. (1972). On the symptoms of 'Green spot' and 'Crape' in nori (Porphyra) culture. Bull. Nansei Reg. Fish. Res. Lab. 5: 1-10 (Japanese, English summary)

Suto, S., Saito, Y., Akiyama, K., Umebayashi, O. (1972). Text book of diseases and their symptoms in Porphyra. Bull. Tokai Reg. Fish. Res. Lab. 18: 1-37 (Japanese)

Suto, S., Umebayashi, O. (1954). On the perforation disease of Porphyra (asakusa-nori). Bull. Jap. Soc. scient. Fish. 19 (12): 1176-1178 (Japanese)

Tsukidate, J. (1983). On the symbiotic relationship between Porphyra species and attached bacteria, and a bacterial pathogen in white rot. Bull. Nansei Reg. Fish. Res. Lab. 15: 29-96

Manuscript first received: January 4, 1989

Revised version accepted: June 22, 1989 